\title{
Cerrahi olarak menopoz oluşturulmuş sıçanlarda melatonin tedavisinin östrojen, progesteron ve vitamin D'nin serum düzeylerine etkisi
}

\author{
The effect of melatonin on serum levels of estrogen, progesterone and \\ vitamin $D$ in a rat model of surgically induced menopause
}

\author{
Esra Bihter Gürler (B) Berrak Çağlayan Yeğen (D) \\ Marmara Üniversitesi Tıp Fakültesi, Fizyoloji Anabilim Dalı, İstanbul, Türkiye
}

Öz

Amaç: Bifosfonatlar menopoz sonrası osteoporozda kemik kütlesinin korunması amacıyla sıklıkla kullanılmaktadır. Melatonin kemik metabolizmasında da düzenleyici rolü olduğu düşünülen bir antioksidan hormondur. Ancak seks hormonları ve Vitamin D düzeylerine etkisi daha önce çalışılmamıştır.

Gereç ve Yöntem: Anestezi altında, Sprague-Dawley sıçanlara $(n=40)$ bilateral overektomi (OVT) ve taklit cerrahi $(n=8)$ uygulanmıştır. Cerrahiden dört hafta sonra OVT'li sıçanlar serum fizyolojik $(1 \mathrm{ml} / \mathrm{kg} / \mathrm{gün})$, melatonin $(25 \mathrm{mg} / \mathrm{kg} / \mathrm{gün})$, alendronat $(70 \mu \mathrm{g} / \mathrm{kg} / \mathrm{hafta})$ veya melatonin + alendronat ile sekiz hafta tedavi edilmişlerdir. Sıçanlar dördüncü $(n=8)$ ve 12. haftanın $(n=12)$ sonunda kalpten kan alınarak sakrifiye edilmiştir.

Bulgular: Overektomiden sonraki dördüncü ve 12. haftalarda serum östrojen seviyelerindeki düşüş $(p<0,05)$ melatoninle kontrol düzeyine dönmüştür $(p<0,001)$. Ancak melatonin+alendronatla tedavi edilen gruplarda bir değişiklik görülmemiştir. Öte yandan, 12. haftanın sonunda OVT grubunda progesteron düzeylerinde bir değişiklik görülmezken, melatonin, alendronat veya kombine tedavi yapılan gruplarda anlamlı bir artış saptanmıştır $(p<0,05-0,001)$. Seks hormon bağlayıcı globülin düzeylerinde OVT gruplarının hiçbirinde farklıık oluşmamış, fakat melatonin grubunda anlamlı olmayan bir yükseliş eğilimi gözlenmiştir. Benzer olarak, yalnızca melatonin tedavili grupta Vitamin D düzeylerinde anlamlı bir artış bulunmuştur. ( $p<0,01-0,001)$.

Sonuç: Bulgularımız melatoninin over-dışı seks hormonlarının ve Vitamin D'nin sentezinde bir rolü olduğunu düşündürmektedir. Melatoninin hormon replasman tedavisinde yeni bir terapötik ajan olarak kullanılabilmesi için klinik araştırmalara gereksinim vardır.

Anahtar Sözcükler: Menopoz, alendronat, melatonin, östrojen, hormon replasman tedavisi.

\begin{abstract} vitamin $D$ was not studied before.

\footnotetext{
Yazışma Adresi: Esra Bihter Gürler

Marmara Üniversitesi, Tıp Fakültesi, Fizyoloji Anabilim Dalı,

İstanbul, Türkiye

E-mail: ebgurler@gmail.com

Makalenin Geliş Tarihi: 20.12.2018 Kabul Tarihi: 11.03.2019
}

Aim: In order to maintain bone mass in post-menopausal osteoporosis, bisphosphonates (e.g. alendronate) are frequently used, while the antioxidant agent melatonin was also suggested to have a regulatory role in bone physiology. However, their impact on the serum levels of sex hormones and

Materials and Methods: Under anesthesia, Sprague-Dawley rats $(n=40)$ underwent bilateral ovariectomy (OVT), while control group had sham surgery $(n=8)$. Four weeks after the surgery, OVT rats were treated with saline $(1 \mathrm{ml} / \mathrm{kg} /$ day $)$, melatonin $(25 \mathrm{mg} / \mathrm{kg} /$ day $)$, alendronate $(70 \mu \mathrm{g} / \mathrm{kg} /$ week $)$ or melatonin + alendronate for 8 weeks. Rats were euthanized at the end of 4 th $(n=8)$ or 12th weeks $(n=40)$.

Results: At the $4^{\text {th }}$ and $12^{\text {th }}$ weeks after OVT, serum levels of estrogen were depressed $(p<0.05)$, while melatonin abolished the reduction in estrogen $(p<0.01)$, but OVT-induced reduction in estrogen levels was still evident in alendronate or melatonin + alendronate-treated groups. 
Despite that progesterone levels were not significantly changed by OVT on the $12^{\text {th }}$ week, melatonin, alendronate or their combination elevated progesterone levels $(p<0.05-0.001)$. Sex hormone binding globulin was not altered significantly in none of the OVT groups, while a tendency to increase was observed by melatonin treatment. Similarly, in only melatonin-treated group, serum levels of Vitamin $D$ were elevated significantly $(p<0.01-0.001)$.

Conclusion: The results implicate that melatonin may have an impact on the extraovarian synthesis of sex hormones and vitamin $D$, suggesting its clinical investigation as a potential therapeutic agent for hormone replacement therapy.

Keywords: Menopause, alendronate, melatonin, estrogen, hormone replacement therapy.

\section{Giriş}

Postmenopozal osteoporoz; dünyada 60 yaş üstü 200 milyon kadının karşı karşıya kaldığı, başlıca kemik kütlesinin kaybı, ağrı ve hareket kabiliyetinde kısıtlılık yaratan, prevalansı oldukça yüksek, kemik kütlesinin kaybı, kemiğin mikroyapısının bozulması, artmış kırık riski ile karakterize, kemik yapım/yıkım oranının bozulduğu metabolik bir kemik hastalığıdır (1-3). Osteoporozlu hastaların tedavisinde birincil derecedeki hedef; kırık riskini ortadan kaldırmak, ağrıyı azaltmak ve fonksiyonu yeniden kazandırmaktır (4). Bu amaçla paratiroid hormon, RANKL inhibitörleri ve selektif östrojen reseptör modülatörleri kullanılan ilaçlar arasındadır. Tüm dünyada osteoporoz tedavisinde ilk sırada kullanılan ilaçlar bifosfonatlardır ve tedavideki altın standardı oluştururlar (5). Yapılan istatistikler bifosfonatların ortaya çıkardığı yan etkileri ortaya koymaktadır. Bu etkiler arasında sık görülenler üst gastrointestinal yan etkiler, akut faz reaksiyonu, hipokalsemi ve sekonder hiperparatiroidi, kas iskelet sistemi ağrıları, çene osteonekrozu ve göz şikayetleridir (6). Bu yan etkilere ek olarak uzun dönem kullanımlarında ortaya çıkan atipik kırılmalar (7) daha güvenilir ama aynı zamanda iyileştirici tedavi seçeneklerine gereksinim olduğunu göstermektedir.

Östrojen eksikliği osteoklast apoptozuna engel olarak osteoklast sayısının artmasına, böylelikle de kemikte yıkım oluşmasına neden olur $(8,9)$. Östrojen, aynı zamanda osteoblastlar ve osteoklastlar üzerinde etkinliği bilinen 1,25 dihidroksivitamin D3'e bağımlı kalsiyum absorpsiyonu üzerine de etkilidir (10). Çalışmalar 1,25 dihidroksivitamin D3 konsantrasyonlarının menopozdan sonra düştüğüne işaret etmektedir (11-13). Östrojen ve diğer seks steroidlerine bağlanan ve bu hormonların hedef hücrelerdeki işlevini düzenleyen seks hormon bağlayıcı globülinin (SHBG) kan düzeylerinin de kemik mineral yoğunluğu (BMD) ile ters bir korelasyona sahip olduğunu, kadınlarda ve erkeklerde osteoporoz ve osteoporoz nedeniyle oluşan kırıklarla ilişkili olduğunu gösteren sınırlı sayıda veri mevcuttur (14-17). Normal fizyolojik koşullarda kadınlarda östrojen ve progesteron bir arada çalışır ve osteoporozda östrojen yokluğu ile beraber progesteron yokluğu da söz konusudur. Yapılan az sayıda in-vitro çalışma progesteronun osteoblast sayısını artırmada, osteoblast olgunlaşmasını ve farklılaşmasını uyarmadaki rolünü göstermiştir (18). Yine bir meta-analitik derleme, kombine progesteron ve östrojen tedavisinin postmenopozal osteoporozda tek başına östrojenden daha etkili olduğunu göstermiştir (10).

Melatonin; başlıca pineal bezden salgılanan, güçlü anti-inflamatuvar etkileri olan ve farmakolojik dozlarda bile toksisitesi olmayan bir hormondur. Salgılanan melatonin miktarının yaşla ters orantılı olduğu bilinmektedir (19). Bu bulgu, melatoninin kemik metabolizması ve östrojenle olan ilişkisinin araştırılmasında ilk adım olmuştur. Yapılan pek çok in-vitro ve in-vivo çalışmanın sonuçları, melatoninin hem östrojen üzerine hem de kemik hücreleri üzerine olan destekleyici etkisine işaret etmektedir (20-24). Buna karşın, osteoblastlar üzerindeki uyarıcı etkisi nedeniyle yeni bir farmakolojik ajan olup olamayacağı tartışmalar arasındadır (20). Bu çalışmada osteoporoz tedavisinde konvansiyonel bir yöntem olarak bilinen bifosfonat tedavisine melatonin eklenmesinin endokrin düzenleyiciler üzerindeki etkileri araştırılmıştır.

\section{Gereç ve Yöntem}

\section{Hayvanlar}

Bu çalışma için Marmara Üniversitesi (M.Ü.) Hayvan Deneyleri Yerel Etik Kurulundan onay alınmıştır (33.2014mar). M.Ü. Deney Hayvanları Merkezinden temin edilen, 250-300 gr ağırlığındaki 48 adet dişi Sprague Dawley sıçan rastgele olarak (kapalı zarf usulü ile) seçilerek gruplandırılmıştır. Sıcaklığı $\left(20-22^{\circ} \mathrm{C}\right)$ ve nemi (\%65-70) korunan ortamda, kafeslerde rahat hareket edebilecekleri şekilde dörderli olarak yerleştirilen sıçanlara, 12 saat/12 saat gündüz/gece ışık uygulanmıştır. Deney süresince yem ve su tüketimleri ad libitum olarak sağlanmıştır. 


\section{Deney Protokolü ve Cerrahi Yöntem}

Overektomi (OVT) uygulamak üzere, anestezi altındaki (Ketamin $100 \mathrm{mg} / \mathrm{kg}$ ve klorpromazin 5 $\mathrm{mg} / \mathrm{kg}$; i.p.) sıçanlarda alt batından transvers insizyon ile ulaşılan overler sütür ile bağlanarak çıkarıldı $(n=40)$. Ardından karın duvarı kapatılarak, $1 \mathrm{ml} / \mathrm{kg}$ cilt altına serum fizyolojik verildi. Taklit cerrahi yapılan kontrol grubundaki hayvanlarda $(n=8)$ ise yine transvers kesi ile overlere ulaşıldı, ancak bir işlem yapılmadan karın duvarı kapatıldı. Dört haftalık bekleme süresinin ardından OVT yapılan hayvanlar rastgele dört gruba ayrılarak tedavilere başlandı ve tedaviler 12. haftanın sonuna kadar sürdürüldü (Şekil-1). OVT'li sıçanlar sekiz hafta boyunca; taşıyıcı serum fizyolojik (SF, $1 \mathrm{ml} / \mathrm{kg} / \mathrm{gün}$, cilt altı), alendronat (Sodium alendronate trihydrate, Sigma-Aldrich Co. LLC, Almanya $70 \mu \mathrm{g} / \mathrm{kg} / \mathrm{hafta}$, cilt altı), melatonin (Sodium alendronate trihydrate, Sigma-Aldrich Co. LLC, Almanya; 25 mg/kg/gün, oral) + SF ya da melatonin + alendronat ile tedavi edildiler (24-26).

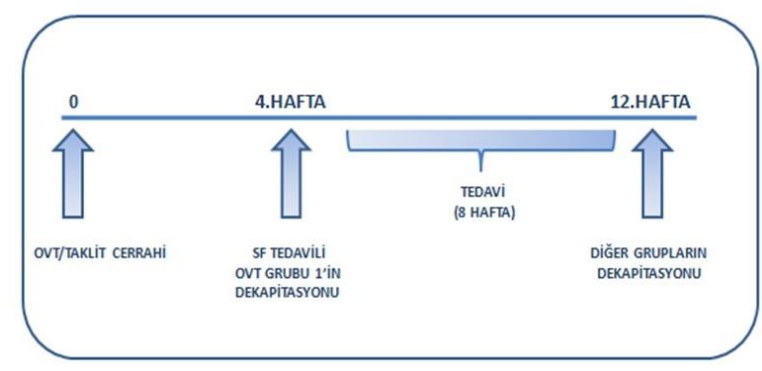

Şekil-1. Deney protokolü.

OVT sonrası, bir grup sıçan henüz tedavilerine başlanmadan dördüncü haftada $(n=8)$ olmak üzere, diğer OVT grupları ve taklit cerrahi yapılan grup da deneysel protokolün 12. haftasının sonunda anestezi altında (Ketamin $100 \mathrm{mg} / \mathrm{kg}$ ve klorpromazin 3-5 mg/kg; i.p.) kalpten kardiyak ponksiyon ile kan alınmasını takiben sakrifiye edildiler. Kan örnekleri 10000 rpm'de, $+4^{\circ} \mathrm{C}$ 'de santrifüje edildi. Ayrılan serumlar östrojen, progesteron, SHBG ve vitamin D seviyelerine bakılmak üzere, $-80^{\circ} \mathrm{C}$ 'de saklandı. Serum örneklerinde östrojen, progesteron, SHBG ve vitamin $D$ düzeylerinin ölçümleri; ticari ELISA (Enzyme-Linked Immuno Sorbent Assay) kitleri (Sun Red, Şangay, Çin) kullanılarak, üretici tarafından verilen talimatlara uygun şekilde yapılmıştır.

\section{İstatistiksel Yöntem}

Verilerin değerlendirilmesinde GraphPad yazılımı (Prism 6,0) kullanıldı. Veriler ortalama \pm standart hata şeklinde ifade edildi. Parametrik verilerin analizi tek yönlü ANOVA ve post hoc Tukey testleri ile yapıldı ve $p<0,05$ istatistiksel olarak anlamlı kabul edildi.

\section{Bulgular}

Cerrahi işlemin menopoz oluşturmada ne kadar etkin olduğunu ortaya koymak üzere overektomi yapılmış sıçanlardan bir grup dördüncü haftada sakrifiye edildi. Serum östrojen düzeyinin, taklit cerrahi yapılmış kontrol grubuna göre dördüncü haftada anlamlı olarak düştüğü bulundu $(p<0,05$; Şekil-2). Östrojen düzeyinin 12. haftada da benzer şekilde düşük olduğu ancak dördüncü haftadaki ölçümlerden farklı olmadığı görüldü. Alendronat tedavisi alan OVT'li sıçanlarda da, SF tedavisi alanlar gibi östrojen düzeyinin düştüğü gözlendi $(p<0,05)$. Ancak, oral olarak melatonin tedavisi alan grupta östrojen düzeylerinin kontrol grubundan farklı olmadığı ve SF-tedavili gruba göre anlamlı olarak yüksek olduğu görüldü $(p<0,01$; Şekil-3A). Buna karşın melatonin ile birlikte alendronat tedavisi alan sıçanlarda östrojen düzeyinin düşük olduğu ve SF-tedavili gruptan farklı olmadığı izlendi $(p<0,05)$. Progesteron düzeylerinde SF tedavili OVT grubunda kontrol grubuna göre bir değişiklik izlenmedi, ancak hem tek başına alendronat ya da melatonin tedavilerinin hem de melatonin + alendronat tedavisinin progesteron düzeyini kontrol grubuna kıyasla anlamlı olarak artırdığı gözlendi $(p<0,05-0,001$; Şekil-3B). Seks hormon bağlayıcı globülin düzeyleri gruplar arasında farklılık göstermedi. Ancak, yalnız melatonin tedavisi alan grupta bir artış gözlense de istatistiksel olarak anlamlı bulunmadı (Şekil-3C).

Vitamin D düzeyleri, SF-tedavili OVT grubunda taklit cerrahi yapılmış kontrol grubundan farklı bulunmadı. Buna karşın, tek başına melatonin tedavili grupta, vitamin D düzeyinin hem kontrol, hem de SF-tedavili OVT grubuna göre anlamlı olarak yüksek olduğu görüldü ( $p<0,01-0,001$; Şekil-3D). Tek başına alendronat tedavisinin ya da melatonin ile kombine verilmesinin vitamin $D$ düzeyinde kontrol grubuna göre değişiklik oluşturmadığı gözlendi.

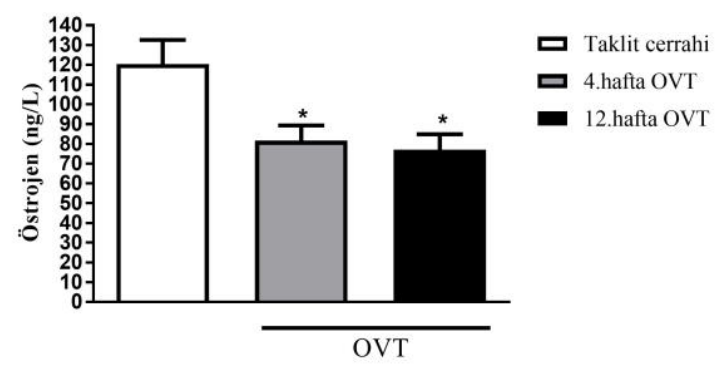

* Ortalama \pm standart hata, $n=8$ sıçan/grup; * $p<0,05$ taklit cerrahi kontrol grubuna göre

Şekil-2. Overektomi sonrası dördüncü ve 12. haftalarda serum östrojen düzeyleri. 


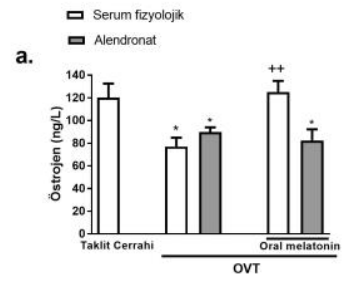

c.
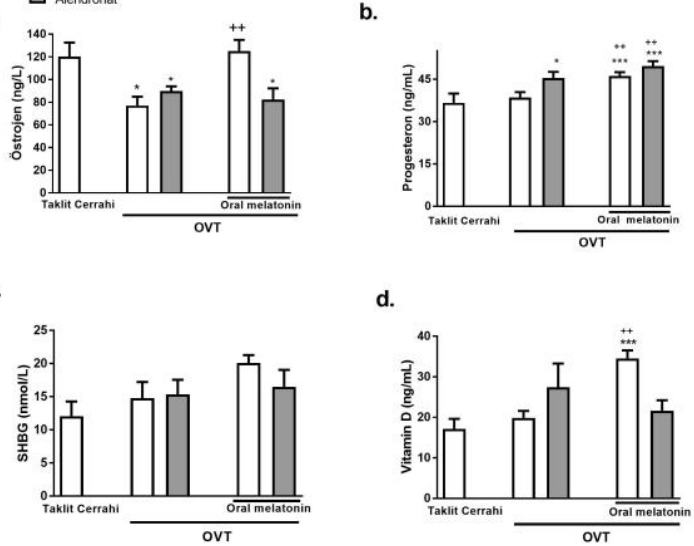

* Ortalama ${ }^{* * *} p<0,001$, taklit cerrahili kontrol grubuna göre; $+p<0,05$, $++p<0,01,+++p<0,001$, Serum fizyolojik (SF) tedavili overektomi (OVT) grubuna göre

Şekil-3. Serumda östrojen, progesteron, seks hormon bağlayıcı globulin, vitamin $D$ düzeyleri.

\section{Tartışma}

Çalışmamızda, cerrahi olarak menopoz oluşturulmuş sıçanlarda, cerrahi sonrası dördüncü haftada başlanıp sekiz hafta süren melatonin tedavisinin serumda östrojen, progesteron ve vitamin $D$ düzeylerini artırdığı ve istatistiksel olarak anlamlı bulunmasa da, SHBG düzeyinde de artışa neden olduğu görüldü. Melatoninin bu etkilerinin, progesteron hariç, menopoz tedavisinin öncü tedavisi olan alendronat ile tedavi sonucunda gözlenmediği ortaya kondu.

Östrojen, steroidogenez ile sentezlenen bir hormondur. Östrojenin kaynağının overler olduğu bilinmektedir. Öte yandan yapılan çalışmalarda nöroestrojenlerin salgılandığı da gösterilmiştir (27). Pinealektomi, overektomi ve hipofizektomi yapılmış sıçanlarda yapılan çalışmalarda melatoninin adrenal steroidogenezdeki fizyolojik regülasyona etkisi olduğu gösterilmiştir (28-30). Ancak çalışmalar çoğunlukla melatoninin doğal aromataz inhibitörü gibi fonksiyon gördüğü ve steroidogenezin geç evresinde östrojen sentezi üzerinde olumsuz etki yaptığı yönündedir (31-33). In-vitro bir çalışma ise melatoninin progesteron artışını uyardığı ama progesterondan östrojene olan dönüşümde kararlı davranmadığını göstermiştir (34). Sonuçlarımız, tek başına melatonin tedavisinin östrojen düzeyini artırıcı olduğunu, ancak alendronat ile kombine edildiğinde bu etkisinin ortadan kalktığını göstermektedir. Bu sonuçlara dayanılarak, literatürdeki yaygın kanının aksine, melatoninin

östrojen üzerindeki etkisinin uyarıcı olduğu ve bu etkinin mekanizmasının araştırılması gerektiği düşünülmektedir.

Progesteronun kemik yapım/yıkım mekanizmasında uyarıcı bir rolü olduğu öne sürülmektedir (35). Insanlarda progesteron, öncelikle overler, düşük miktarda da plasenta ve adrenal bezden sentezlenir ve menopoz öncesi düşmeye başlar $(10,36,37)$. İnsanlardakinin aksine, sıçanlarda ise adrenal bezden sentezlenen progesteronun korpus luteumdan sentezlenen progesteronla eşit ya da daha büyük miktarlarda olduğu gösterilmiştir (38). Bulgularımız, SF-tedavili OVT grubunda progesteron düzeyinde bir değişiklik olmadığını ve değişiklik olmamasından adrenal bez kaynaklı progesteronun sorumlu olacağını göstermiştir. Literatürle uyumlu olacak şekilde, OVT ile progesteronda azalma olmaması türler arasındaki farklılıktan kaynaklanıyor olabilir. Eksojen verilen melatoninin menopoz öncesi kadınlarda progesteron seviyesini artırdığı (39) ve sığır granüloza hücrelerinde fizyolojik regülasyonda rol oynadığı gösterilmiştir (40). Çalışmamızda da benzer şekilde hem melatonin hem alendronat tedavisi hem de ikisinin kombinasyonu progesteron düzeyini kontrol grubuna ve SFtedavili OVT grubuna göre artırmıştır.

Alendronat varlığında gözlenen progesteron artışının alendronatın kemik yıkımı üzerindeki baskılayıcı etkisinden kaynaklanabileceği düşünülse de mekanizmasının açıklanmasına intiyaç vardır. Her ne kadar sıçandaki progesteron düzeyi insanda olduğunun aksine OVT sonrasında azalmadıysa da, melatoninin, önceki çalışmaları destekleyecek şekilde progesteron düzeyini artırması ve bunu pek çok yan etkisi bulunan alendronata benzer şekilde yapması, melatoninin menopoz tedavisinde destekleyici rolü olabileceğini düşündürmektedir.

Serbest seks steroidlerinin indeksleri ve SHBG bölünen kemik hücreleri durumunun sık kullanılan indikatörleridir. SHBG, kemik yıkımı işaretleyicilerinden olan osteokalsin ve bir telopeptit olan $\mathrm{N}$-terminal cross-linked telopeptide ile ters korelasyona sahiptir. Bununla beraber SHBG konsantrasyonu ile kemik kırığı riski arasında da ters korelasyon olduğu gösterilmiştir $(41,42)$. Ancak literatürde SHBG ile ilgili çalışmalar sınırıdır. SHBG düzeyinin seks steroidlerinin biyoyararlanımını etkilediği bilindiğine göre (43) kemik mineral yoğunluğu, 
kemik yapımı ve fraktür sayısı ile SHBG düzeyleri arasındaki ilişkinin göz önüne alınması gereklidir. Literatürle uyumlu olarak, çalışmamızda SHBG düzeyleri tüm gruplarda kontrolden farklı bulunmamıştır. Bu sonuç da, melatoninin östrojen ve progesteron düzeylerini artırıcı etkisinin SHBG düzeyinde bir artış olmadan gerçekleştiğini düşündürmektedir.

Yapılan çalışmaların sonucunda, vitamin D3 konsantrasyonunun menopozdan sonra düştüğü $(11,12,13)$ fakat hormon replasman tedavisi (HRT) ile bu konsantrasyonların yükseldiği bilinmektedir $(11,44,45)$. Çalışmamızda vitamin D düzeyinin yalnızca melatonin tedavili grupta anlamlı derecede yükseldiği ortaya konmuştur. $\mathrm{Bu}$ artışın insanlardaki HRT ile olduğu gibi, melatonin ile artan östrojen ve progesterona bağlı olduğu düşünülebilir. Buna karşın, literatürde melatoninin vitamin D'nin nöroimmunomodülatör rolünün potansiyel bir mediyatörü olabileceğini öne süren bir çalışma mevcuttur (46). Bu da, melatonin tedavisi ile olan anlamlı artışın melatoninin vitamin $\mathrm{D}$ üzerindeki direkt modülatör etkisi ile ortaya çıkmış olabileceğini düşündürmektedir. Alendronat varlığında ise, melatoninin vitamin D'yi artırıcı etkisinin ortadan kalkması, alendronatın osteoklastik aktiviteyi inhibe edici özelliğinden kaynaklanıyor olabilir (7).

\section{Sonuç}

Cerrahi menopoz sonrası iki ay sürdürülen melatonin tedavisi sıçanlarda menopoza bağlı olarak düşüş gösteren östrojen düzeylerini ve insandan farklı bir şekilde, menopozla değişiklik göstermeyen progesteron ve vitamin $D$ düzeylerini artırmıştır. Melatoninin östrojen ve vitamin D'yi artırıcı etkileri, osteoporoz tedavisinde kullanılan alendronat tedavisi ile gözlenmemiştir. Hormon düzeylerindeki düşüşleri azaltarak melatoninin osteoporozun ilerlemesini geciktirebileceği ön görülebilir. Ancak, over dışı steroid hormon sentezi farklılık gösteren sıçanlarda yapılan bu çalışmanın, klinik çalışmalarla desteklenmesi gerekir. $\mathrm{Bu}$ nedenle melatoninin osteoporoz tedavisinde terapötik bir ajan olarak kullanılabilmesi için östrojen, progesteron, SHBG ve vitamin D düzeyleri üzerindeki etkisinin insanlarda yapılan çalışmalarla da aydınlatılması gerekmektedir.

\section{Kaynaklar}

1. Lofbonehealth.org [homepage on internet]. Nyos: International Osteoporosis Foundation Online Resources [updated 20 November 2018; cited 20 December 2018]. Available from: www.iofbonehealth.org/what-isosteoporosis.

2. Marcucci G, Brandi ML. Rare causes of osteoporosis. Clin Cases Miner Bone Metab 2015; 12 (2): 151-6.

3. Lafleur J, Rillamas-Sun E, Colón-Emeric CS et al. Fracture Rates and Bone Density Among Postmenopausal Veteran and Non-Veteran Women from the Women's Health. Initiative The Gerontologist 2016; 56 (Suppl 1): 78-90.

4. Follin SL, Hansen LB. Current approaches to the prevention and treatment of postmenopausal osteoporosis. Am J Health Syst Pharm 2003; 60 (9): 883-901.

5. Miller PD. Bisphosphonates: Pharmacology and use in the treatment of osteoporosis. In: Marcus R, Feldman D, Nelson DA. Rosen CJ (Eds). Osteoporosis. 3.Ed, San Diego: Elsevier American Pres; 2008: 1725 - 41.

6. Eriksen EF, Halse J, Halse M, Haase M. New developments in the treatment of osteoporosis. Acta Obstetricia et Gynecologica Scandinavica 2013; 92 (6): 620- 36.

7. Odvina CV, Zerwekh JE, Rao DS, Maalouf N, Gottschalk FA, Pak CY. Severely suppressed bone turnover: a potential complication of alendronate therapy. J Clin Endocrinol Metab 2005; 90 (3): 1294-301.

8. Riggs BL, Khosla S, Melton LJ 3rd. A unitary model for involutional osteoporosis: estrogen deficiency causes both type I and type II osteoporosis in postmenopausal women and contributes to bone loss in aging men. $J$ Bone Miner Res 1998; 13 (5): 763-73.

9. Manolagas SC. Birth and death of bone cells: basic regulatory mechanisms and implications for the pathogenesis and treatment of osteoporosis. Endocr Rev 2000; 21 (2): 115-37.

10. Seifert-Klauss V, Prior JC. Progesterone and bone: actions promoting bone health in women. J Osteoporosis 2010: 845180.

11. Gallagher JC, Riggs BL, Eisman J, Hamstra A, Arnaud SB, De Luca HF. Intestinal calcium absorption and serum vitamin $D$ metabolites in normal subjects and osteoporotic patients: effect of age and dietary calcium. $J$ Clin Invest 1979; 64 (3): 729-36.

12. Sørensen $\mathrm{OH}$, Lumholtz B, Lund B, Lund B et al. Acute Effects of Parathyroid Hormone on Vitamin D Metabolism in Patients with the Bone Loss of Aging. The Journal of Clinical Endocrinology \& Metabolism 1982; 54 (6): 1258-61. 
13. Lawoyin S, Zerwekh JE, Glass K, Pak CY. Ability of 25 -hydroxyvitamin D3 therapy to augment serum 1,25 and 24, 25-dihydroxyvitamin D in postmenopausal osteoporosis. J Clin Endocrinol Metab 1980; 50 (3): 593-6.

14. Cummings SR, Browner WS, Bauer D, et al. Endogenous hormones and the risk of hip and vertebral fractures among older women. Study of Osteoporotic Fractures Research Group. N Engl J Med 1998; 339 (11): 733-8.

15. Alexandre C. Androgens and bone metabolism. Joint Bone Spine 2005; 72 (3): 383-7.

16. Khosla, S. Role of Hormonal Changes in the Pathogenesis of Osteoporosis in Men. Calcif Tissue Int 2004; 75 (2): 110.

17. Hoppé E, Bouvard B, Royer M, Audran M, Legrand E. Sex hormone-binding globulin in osteoporosis, Joint Bone Spine 2010; 77 (4): 306-12.

18. Melton LJ, Riggs BL Jr. Further characterization of the heterogeneity of the osteoporotic syndromes. In: Kleerekoper M, Krane SM (Eds). Proceedings of the International Symposium on Clinical Disorders of Bone and Mineral Metabolism. New York: Mary Ann Liebert, Inc 1989; 145-52.

19. Roth JA, Kim BG, Lin WL et al. Melatonin Promotes Osteoblast Differentiation and Bone Formation. Journal of Biological Chemistry 1999; 274 (31): 22041-7.

20. Cardinali DP, Pévet P. Basic aspects of melatonin action. Sleep Med Rev 1998 Aug; 2 (3): 175-90.

21. Reiter RJ, Tan DX, Allegra M. Melatonin: reducing molecular pathology and dysfunction due to free radicals and associated reactants. Neuro Endocrinol Lett 2002; 23 (Suppl 1): 3-8.

22. Ladizesky MG, Boggio V, Albornoz LE et al. Journal of Pineal Research Melatonin increases oestradiolinduced bone formation in ovariectomized rats.2003; 34 (2): 143-51.

23. Ladizesky MG, Boggio V, Cutrera $R$ et al. Melatonin effect on bone metabolism in rats treated with methylprednisolone. Journal of Pineal Research 2006: 40 (4): 297-304.

24. Maria S, Witt-Enderby PA. Melatonin effects on bone: potential use for the prevention and treatment for osteopenia, osteoporosis, and periodontal disease and for use in bone-grafting procedures. Journal of Pineal Research 2014; 56 (2): 115-25.

25. Nakao S, Minamide A, Kawakami M, Boden SD, Yoshido M. The Influence of Alendronate on Spine Fusion in an Osteoporotic Animal Model Spine. 2011; 36 (18): 1446-52.

26. Raghavendra V, Shrinivas K, Kulkarni A. Melatonin reversal of DOI-induced hypophagia in rats; possible mechanism by suppressing 5-HT2A receptor-mediated activation of HPA axis, Brain Research 2000; 860 (12): $112-8$.

27. Kenealy BP, Kapoor A, Guerriero KA et al. Neuroestradiol in the hypothalamus contributes to the regulation of gonadotropin releasing hormone release. J Neurosci 2013; 33 (49): 19051-9.

28. Ogle TF, Kitay Jl. Effects of melatonin and an aqueous pineal extract on adrenal secretion of reduced steroid metabolites in female rats, Neuroendocrinology 1977; 23 (2): 113-20.

29. Malendowicz LK, Majchrzak M, Nowak M. Estradiol and melatonin effects on adrenal cortex of ovariectomized and pinealectomized rats. Exp Clin Endocrinol 1985 Jun; 85 (3): 276-82.

30. Maganhin CC, Simões RS, Fuchs LP Sasso GRS et al. Melatonin influences on steroidogenic gene expression in the ovary of pinealectomized rats, Fertility and Sterility 2014; 102 (1): 291-8.

31. Chottanapund S, Van Duursen MBM, Navasumrit $P$ et al. Anti-aromatase effect of resveratrol and melatonin on hormonal positive breast cancer cells co-cultured with breast adipose fibroblasts, Toxicology in Vitro 2014; 28 (7): 1215-21.

32. Bondi CD, Alonso-Gonzalez C, Clafschenkel WP et al. The effect of estradiol, progesterone, and melatonin on estrous cycling and ovarian aromatase expression in intact female mice. European Journal of Obstetrics Gynecology and Reproductive Biology 2014; 174: 80-5.

33. Alvarez-García V, González A, Martínez-Campa C, Alonso-González C, Cos S. Melatonin modulates aromatase activity and expression in endothelial cells. Oncol Rep 2013; 29 (5): 2058-64.

34. Webley GE, Leidenberger F. The circadian pattern of melatonin and its positive relationship with progesterone in women. J Clin Endocrinol Metab 1986 Aug; 63 (2): 323-8.

35. Prior JC. Progesterone for Symptomatic Perimenopause Treatment - Progesterone politics, physiology and potential for perimenopause. Facts Views Vis Obgyn. 2011; 3 (2): 109-20.

36. Norman AW ve Litwack G. Hormones. Orlando: Academic press. 1987. Norman AW ve Litwack G. Hormones (2nd Ed.). Academic Press USA, 1997; 361-384.

37. Balfour WE, Comline RS, Short RT. Secretion of Progesterone by the Adrenal Gland. Nature 1957; 180:1480-1. 
38. Fajer $A B$, Holzbauer $M$ ve Newport $H$. The contribution of the adrenal gland to the total amount of progesterone produced in the female rat. J. Physiol 1971214 (1): 115-26.

39. Taketani T, Tamura H, Takasaki A et al. Protective role of melatonin in progesterone production by human luteal cells. J Pineal Res 2011; 51 (2): 207-13.

40. Wang SJ, Liu WJ, Wu CJ et al. Melatonin suppresses apoptosis and stimulates progesterone production by bovine granulosa cells via its receptors (MT1 and MT2). Theriogenology 2012; 78 (7): 1517-26.

41. Schlaghecke R, Beuscher D, Kley HK, Juli E. Age-related changes in 11 beta hydroxy androstenedione concentration in normal and osteoporotic women. J Steroid Biochem Mol Biol 1991; 40 (4-6): 731-3.

42. Varsavsky M, Reyes-García R, García-Martín A, Ramírez RG, Avilés-Perez MD, Muñoz-Torres M. SHBG levels are associated with bone loss and vertebral fractures in patients with prostate cancer. Osteoporosis International 2013; 24 (2): 713-9.

43. Pardridge WM. Serum bioavailability of sex steroid hormones. Clin Endocrinol Metab. 1986; 15 (2): $259-78$.

44. Lund B. Sorensen $\mathrm{OH}$, Lund B, Agner E. Serum 1,25 $(\mathrm{OH}) 2 \mathrm{D}$ in normal subjects and in patients with postmenopausal osteopenia. Influence of age, renal function and estrogen therapy, Horm Met Res $1982 ; 14$ (5): 271-4.

45. Stock JL, James A, Coderre E, Lawrence E, Malette E. Effects of a Short Course of Estrogen on Mineral Metabolism in Postmenopausal Women, The Journal of Clinical Endocrinology \& Metabolism 1985; 61 (4): 595600.

46. Golan D, Staun-Ram E, Glass-Marmor L et al. The influence of vitamin D supplementation on melatonin status in patients with multiple sclerosis, Brain, Behavior, and Immunity 2013; 32: 180-5. 